\title{
Motivation of Online Buyer Behavior
}

\author{
Svatošová Veronika
}

\begin{abstract}
Buyer behavior of consumers plays one of the key roles in fulfillment of the main goals of a company. It is influenced by many external and internal factors but the company can also influence the final process of buyer decision-making process significantly by its activities. The subject matter of this article is an analysis of the features of online buyer behavior compared to the general regularities of buyer behavior, definition of the main motives of online shopping, and description of the current trends. The article uses the basic terminology of this subject and current bibliography as well as other resources. Theoretical knowledge is based on historic directions of Maslow's theory of motivation where it is possible to find the basis for a buyer behavior analysis. The article is also based on the formerly carried out questionnaire survey which examines the motives and experience of the respondents with online shopping. By means of the independence test it is verified whether there is a relation between the age of respondents and motivation for online shopping. Subsequently, the survey carried out in person is compared with other relevant research solutions.
\end{abstract}

Keywords: E-business, E-commerce, Internet, Marketing, Marketing Research, Maslow's Hierarchy of Needs, Motivation, Online Buyer Behavior

\section{INTRODUCTION}

Buyer behavior of consumers plays one of the key roles for fulfillment of the main goals of a company. It is influenced by many external and internal factors but the company can also influence the final process of buyer decision-making process significantly by its activities. Buyer behavior of consumers is subject of many researches, mainly in the area of marketing, as it is of crucial importance for company success. Consumer behavior on the Web has been the subject of considerable research in the last few years, but understanding it is made difficult by the fact that the main entities involved, consumers and businesses, have benn transformed (Koufaris, 2002). It is clear that this area influences many aspects of the current online and offline business. The subject of this article is to identify them.

However, various models of consumer behavior have been established that could be of great use since, after all, homepages could be considered to be advertisements, thanks to their conceptual similarity, physical appearance and functions fulfilled (Singh and Dalal, 1999). Attitude can be considered one of the most important concepts in the study of consumer behavior as, according to the literature, it is the direct determinant of this behavior. This functional view of attitude suggests that people hold attitudes to determine how to respond to their environment (Castaneda et al., 2009)

The aim of the article is to analyze the specific features and motives of online buyer behavior in B2C business, description of current trends and possible prediction of its further development. As the starting point for achievement of the goals of the article, Maslow's theory of motivation is used and a questionnaire survey is made focused on the motives of online buyer behavior of selected respondents. 


\section{BUYER BEHAVIOR IN GENERAL}

The issues of buyer behavior are already characterized directly or indirectly by some directions in the historic development of management. They include psychological and social approaches which pay significant attention to motivation. The subject matter of interest of these approaches is primarily the issues of the management style, focus on the employees of the company and efficient interpersonal communication. Despite that, in these theories it is also possible to find some inspiration for understanding of principles and motives of buyer behavior of consumers. The representatives of this style of thinking are for example D. McGregor, A. Maslow, F. Herzberg, C. P. Alderfer, D. McClelland, V.H. Vroom, L.W. Porter and others (Blažek, 2011). Humanistic management theories, the main representative of which is A. Maslow, emphasize an individual development as the basic need of a person. However, there are many people who are not interested in self-improvement and they are only motivated by existential or social needs (Bělohlávek et al., 2001).

Abraham Maslow formulated a hierarchy of needs which divides motives according to five levels of significance. The basic needs are at the bottom of the hierarchy and the highest needs in its top part. However, they do not have to be fully satisfied. The higher we get, the lower the percentage of satisfaction is which is necessary for a higher need to emerge (Solomon et al., 2006). Abraham Maslow believed that provision of physiological needs and feelings of safety is not sufficient for universal motivation of a person. Maslow's hierarchy of needs can be adapted successfully to the market segmentation and preparation of advertising statements as there are goods intended for satisfaction of each level of needs and most needs are shared by large segments of consumers.

Solomon et al. (2006) therefore applied the Maslow's pyramid of needs for understanding of motives of buyer behavior of consumers and subsequent efficient application of marketing communication with potential customers, as human needs - needs of the consumer - are the basis of modern marketing, the core of the marketing conception which is related to the goal of the article:

1. Physiological needs - basic needs (their satisfaction is necessary for survival), such as water, sleep, food, also medicine and goods of everyday use. KFC - "Life Tastes Great!"

2. Needs of safety and security - feeling of safety, absence of fear, provision and maintenance of existence for future. This degree of hierarchy is described well by the insurance, alarm or pension insurance scheme markets. AXA - "Be Life Confident."

3. Social needs - communication with other people, existence of friends (solidarity and love) and building of a position in a certain group. This need can be satisfied by the market with clothes, body care, drinks or clubs. Pepsi - "You Are the Pepsi Generation!"

4. Need of recognition - needs of the ego, prestige, status and success. It includes the market with cars, furniture, credit cards, transactions or exclusive drinks. Honda - "The True Definition of Luxury. Yours."

5. Self-fulfillment - implementation of your own possibilities, how to become all you are able to become, implementation of all your abilities and talents, satisfaction of possibility of education and development, self-fulfillment, enriching experience. US Army - "Be All You Can Be." 
Besides motivation, the consumer decision-making process is influenced by many various factors in the life of the consumer. Marketing specialists must understand this influence and its relative significance in order to be able to make efficient marketing decisions.

A significant role is played here by social conditions, habits, offer and demand and last but not least the sale method and technology. The task of the marketer is to understand the process happening in the customer's mind, starting from the moment when the customer receives stimuli from the outside until making a purchase decision. The factors influencing behavior of the consumer can be divided into two basic groups, external and internal ones. The internal factors include personal and psychological factors and the external ones include cultural and social or demographic factors. Purchases of every individual are influenced by four psychological factors: motivation, perception, learning and attitude. The following figure 1 illustrates the process of buyer behavior of consumers.

\section{EXTERNAL INFLUENCES}

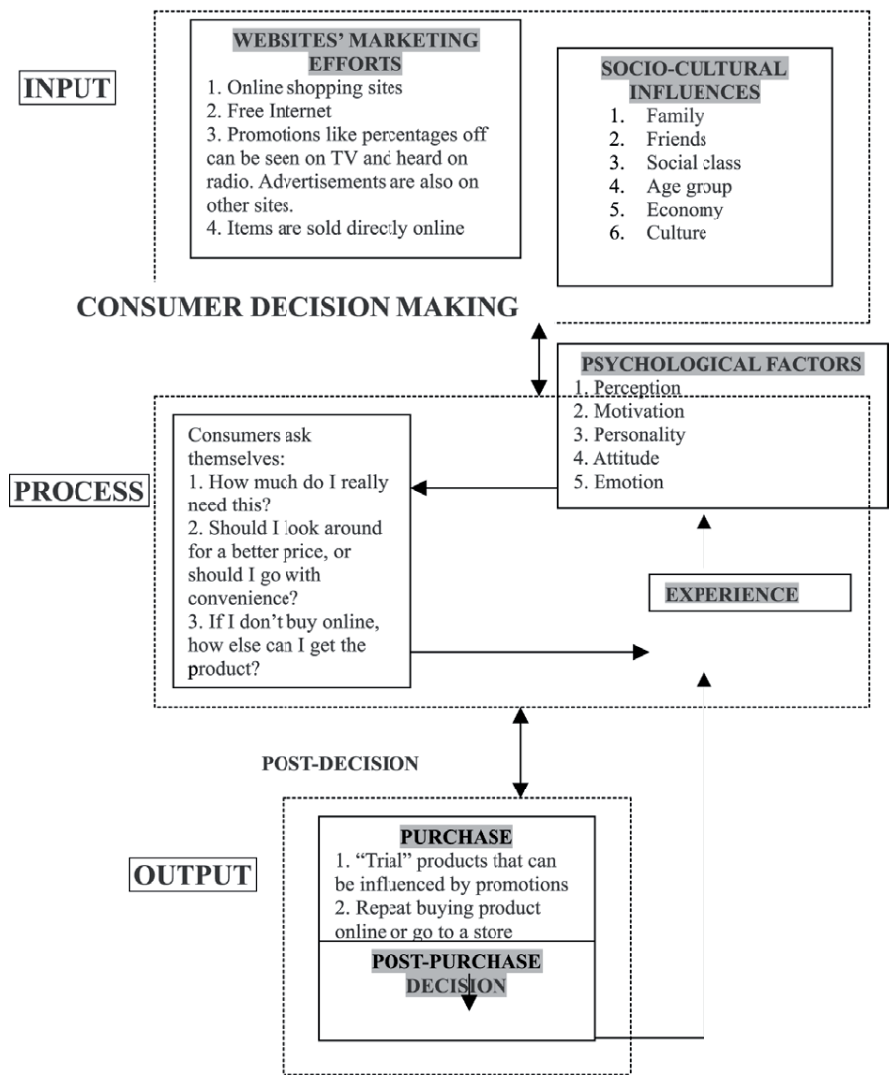

Fig. 1 - Buying decision process. Source: Smith, 1997. 
The basic needs of the consumer do not change but the products which satisfy them change and it will make sure that the company will remain one of the leaders in search for new and efficient solutions. In this way the companies will probably survive and they will develop despite the strong competition or adverse economic conditions (Schiffman, Kanuk, 2004, p. 93 - 94). During the final purchase decision, motivation plays one of the key roles and it represents one of the factors influencing purchase behavior of the consumer.

\section{PROCESS OF ONLINE BUYER BEHAVIOR}

With the existence of online environment, the basic principles of buyer behavior are changing. The following specifics of online buyer behavior are (see the Tab. 1):

Tab. 1 - Specifics of online buyer behavior. Source: own on literature review.

\begin{tabular}{|l|l|}
\hline Internet & $\begin{array}{l}\text { Internet users can find objective and subjective information about the } \\
\text { products and companies easier than ever. Online companies compute } \\
\text { not only to each other but also with potential online customer (posi- } \\
\text { tive and negative references, internet communities, social networks } \\
\text { and social media etc.). Social media provides an interactive communi- } \\
\text { cation between its users. With social media, the marketing activities } \\
\text { had to be reformulated. }\end{array}$ \\
\hline $\begin{array}{l}\text { Modern forms } \\
\text { of marketing }\end{array}$ & $\begin{array}{l}\text { Traditional marketing forms are not in the Internet environment } \\
\text { effective. With the development of e-commerce, new marketing ac- } \\
\text { tivities had to be created - marketing on social networks and media, } \\
\text { viral marketing, online word-of-mouth and buzz marketing, online } \\
\text { interactive communication. Online potential shoppers are interested } \\
\text { in only the marketing activities that can offer for them the value } \\
\text { added (online games and competitions, community identifying with } \\
\text { products and company, online sharing etc.). }\end{array}$ \\
\hline $\begin{array}{l}\text { Internet } \\
\text { community }\end{array}$ & $\begin{array}{l}\text { Internet users discuss about their life style about products and compa- } \\
\text { nies, find detail information about them. Opinion of internet commu- } \\
\text { nity (in social media, discussion forums i.e.) influence the final online } \\
\text { buying decision process. The internet company in its marketing has to } \\
\text { join the internet community and manage the online communication. }\end{array}$ \\
\hline $\begin{array}{l}\text { Online shoppers buy the most - with electronics and techniques, } \\
\text { books, tickets or clothes and cosmetics. The online buying of food is } \\
\text { at the moment the rarity (during the time it is expected the increasing } \\
\text { of online buying of goods). The expectation is that the common buy- } \\
\text { ing will move the online environment. Standardized products such } \\
\text { as books, CDs and tickets are more likely to be purchased online. Be- } \\
\text { cause quality uncertainty in such products is very low, and no physical } \\
\text { help is required (Grewal et al., 2002). }\end{array}$ \\
\hline suline
\end{tabular}




\begin{tabular}{|l|l|}
\hline $\begin{array}{l}\text { Demographic } \\
\text { structure of online } \\
\text { shoppers }\end{array}$ & $\begin{array}{l}\text { Today, online shoppers are the most often between } 18 \text { and } 40 \text { years } \\
\text { and come from the middle-income class. There are differences in } \\
\text { online behavior between the "Facebook generation" and generation } \\
\text { that lived most of their lives without online communication. The } \\
\text { older online generation (up to 50) is increasing - the companies have } \\
\text { to focus on them. }\end{array}$ \\
\hline $\begin{array}{l}\text { Approach a main motives to the online shopping are lower costs, comfort } \\
\text { motives to the } \\
\text { online shopping } \\
\text { of shopping (nonstop and everywhere), saving time and buying of } \\
\text { non-traditional and exclusive goods. The another motives can be the } \\
\text { increasing trends of online shopping in general or changing life styles } \\
\text { on consumers. The question is if these motives are dependent on } \\
\text { social status and role, age, education or income of online shoppers. } \\
\text { Older generation find and try the product on traditional market, after } \\
\text { that they do online shopping. Younger generation make the all buying } \\
\text { decision-making process online. }\end{array}$ \\
\hline
\end{tabular}

The following figure (see Fig. 2) shows the process of online buyer behavior (in online retailing) that involves the main factors influencing the whole process. 


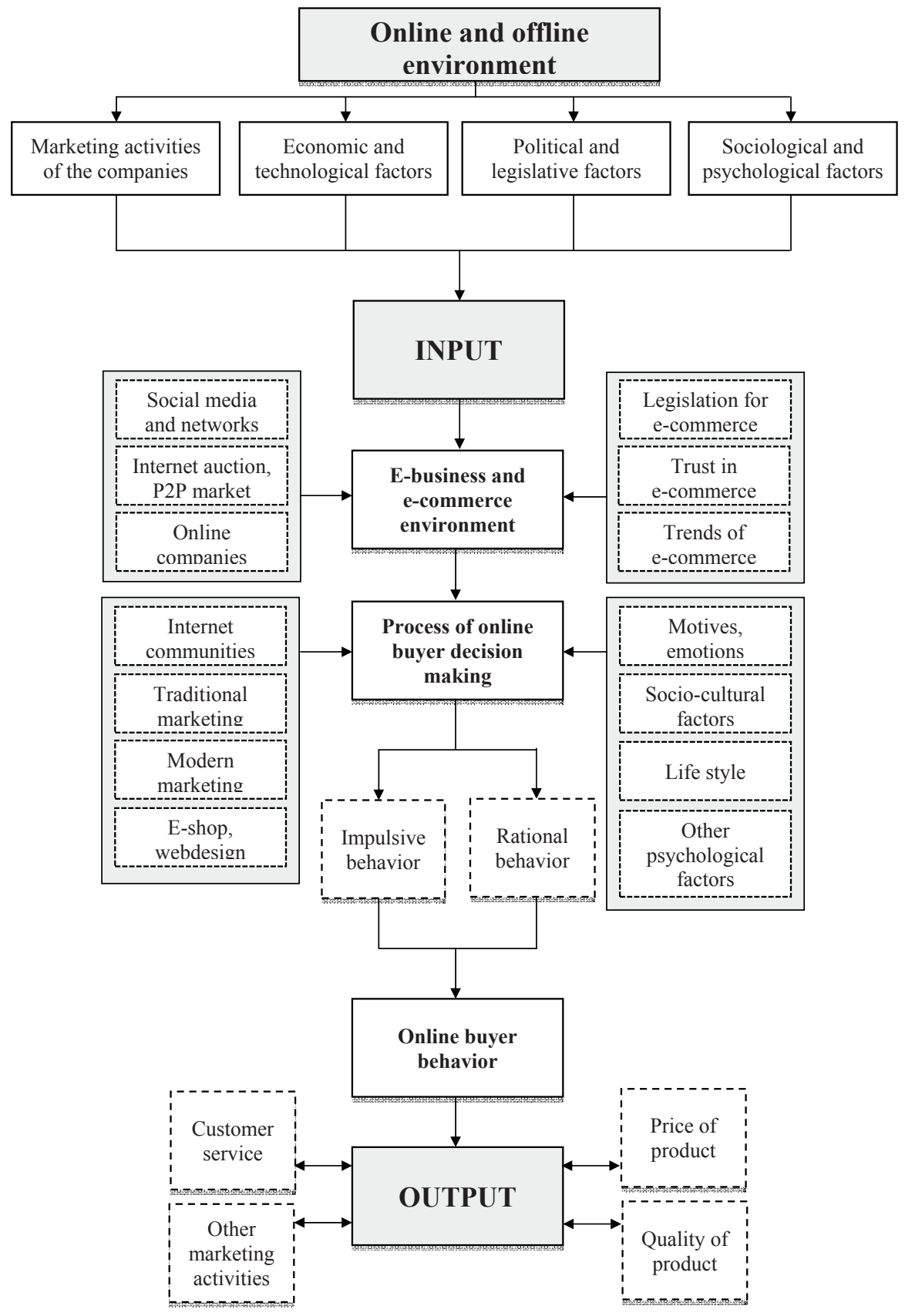

Fig. 2 - The process of online buyer behavior. Source: own. 
The process model respects the global aspects of online and offline behavior (economic, political, legislative, marketing activities of companies, technological, psychological and sociological factors). With the input of the process, it is needed to respect the e-business and e-commerce environment that is influenced by its trends, legislation and consumer trust. This environment is specified according to type and form of online retailing (P2P market and social media and social networks, online companies (B2C) or internet auctions (C2C). The online buyer decisionmaking process is influenced by the two groups of factors - external factors (that come from the sellers and internet communities) and internal factor (like motives, emotions, socio-cultural and other psychological factors). The online buyer decision-making process can be impulsive and rational. Finally, the process ends up with the online buying. The output of this process has an impact on price and quality of the offered products in online and offline environment, customer service and other marketing activities. It is clear that online buyer behavior has very similar features like the ones in the area of the whole market (demographic, psychological, sociological factors). However, there are some specific features here characterizing the actual virtual environment.

Another model about online buyer behavior illustrates the following figure (see Fig. 3) that describes of context of information behavior and buyer-supplier relationship.

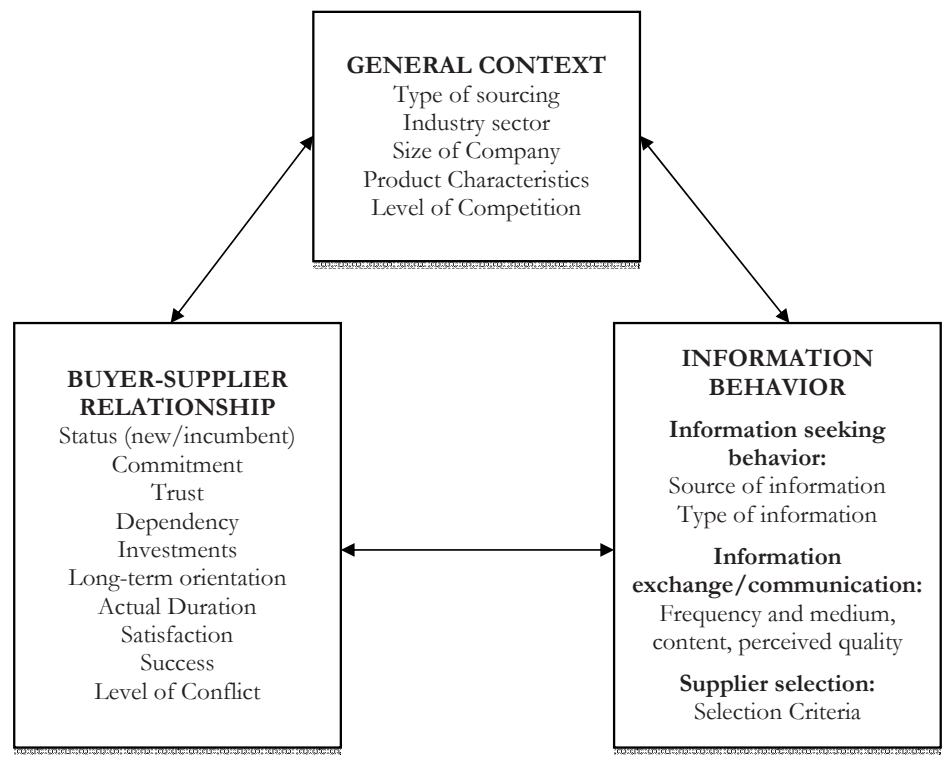

Fig. 3 - Conceptual framework - general context, information behavior and buyer-supplier relationship. Source: Lösch, 2007.

The importance of e-commerce is still growing in the long term. This example demonstrates the development of sales in online stores. The share of online stores in total retail sales in 2011 ranged between 5 - 6\%, which represented 40 to 45 billion CZK (CSO, 2013). According to the Czech Statistical Office (2012) around $27 \%$ of Czech companies are operating electronically. 
These companies grossed over 42 billion CZK (which is $16 \%$ more than in 2011), (CSO, 2012). In 2002, revenues from online orders was 5\% of a company's turnover, in 2010 this share had risen to $25 \%$. These aspects are also influenced by online buyer behavior.

Chaffey (2006) defines the key areas where online customers have high expectation of online retailing. The main areas are: logistics, security and privacy of information, timeliness, availability, convenience, customer service. In the study conducted by Vellido et al. (2000), nine factors connected with users' viewpoint of online shopping were extracted. Among those factors the risk perception of users was showed to be the main discriminator between people shopping online and people not shopping online. Etail Q (Wolfinbarger \& Gilly, 2003) is composed of four factors such as website design, customer service, fulfillment/reliability, and security/privacy. Shergill \& Chen (2005) also measured the quality of e-tail experiences by the same four dimensions. They were website design, customer service, fulfillment/reliability and security/privacy. For e-commerce shopping, another important component is ease of use. It may be described in terms of the time needed to find and buy the products, the convenience of using the shopping engine as part of the purchasing process (Bhatnagar, Misra, \& Rao, 2000). Security and privacy have a powerful effect on customer trust in online shopping (Lee and Turban, 2001). Privacy risk means a customer may sacrifice their privacy when they are required to provide private information in making e-commerce transaction (Vijayasarathy, 2002).

Petrtyl (2006) in his research found out that online consumer expect in online shopping the most - price conditions (79.9\%), speed and quality of delivery $(65.8 \%$ ), assortment $(57.3 \%)$, security and trustworthiness $(89.9 \%)$ or communication with an e-shop (60.3\%). The most frequent problem with online shopping is merchandize or service never delivered $(21.8 \%)$, defective/poor quality $(16.8 \%)$, merchandise or service was not in conformity with order $(12.7 \%)$ or other mispresentation (9.6\%). Chuang and $\mathrm{Hu}$ (2012) confirmed in their research that based on the shopping frequency, different types of online shoppers will perceive these characteristics differently.

Experience and global researches show that only $20 \%$ of all purchases are planned, the remaining $80 \%$ are impulsive, based on emotions. After visiting a shop, customers should get a feeling that traders understand their needs and not only before the purchase is made but also after. This is true even more for selling on the Internet (Kneshke, 2006). According to Pilík's research (Pilík, 2012), $89 \%$ of Czech Internet users use the Internet for purchasing products or services. But only $32.1 \%$ buy online regularly. It means that most Czech Internet users buy online but only irregularly and still prefer and mortar shops for majority of shopping. Czech online customers choose an e-shop mainly based on references, clarity and menu navigation, terms of delivery, graphic design and additional services of the e-shop. It is quite surprising that Czech online customers do not verify e-shops' participations in Internet associations, e-shop's history or they do not read delivery and sales terms.

These secondary sources (Cetelem, 2011; Cimpler, 2005; E15.cz, 2010; ČSÚ, 2011, Gemius, 2010; Měšec.cz, 2010) are focused on research surveys examining the online buyer behavior processes. A research carried out by Barometr Cetelem in 13 European countries, including the Czech Republic, in 2009 showed an increasing interest in online shopping all over Europe. From the research it is clear that most of the European respondents use the Internet as a source of important information before a planned purchase. Most often they search for information about con- 
sumer electronics, culture and cultural events and possibilities of leisure time activities, such as travelling. Compared to the other states, Czech consumers prefer a safer way of buying and they prefer e-shops with connections to a conventional shop. A similar trend is also clear as regards the way of payment on the Internet. The most frequent way is payment for the goods which is physically taken over - cash on delivery (in up to $65 \%$ of cases, the other forms of payment are represented sporadically).

Röszlerová (2010) points out that the Czech customers consider quality of the goods important but to the significant degree they look for and follow special offers and advantageous prices, which also results in purchases of second hand goods and shopping in online shops or auctions. According to Barometer, the Europeans, unlike the Czechs, realize more the fact that their choice of quality products can contribute to the environment protection, to support of fair remuneration for work and to ensure observance of fundamental human rights. On the contrary, according to the study, the Czechs are not influenced too much by ecology or fair trade.

This research showed on a representative sample of respondents that every fourth person at the age of 18 to 65 buys minimum once a month on the Internet. Young people usually choose and buy directly on the Internet, people from 30 to 39 years of age use the Internet only for the actual purchase of goods. A particular product is selected in a conventional shop. For older Czech people from 50 to 65 years of age it is typical to find particular goods on the Internet but they prefer carrying out the actual purchase in a conventional shop.

Another research made in 2009 by Heuréka.cz company in cooperation with Aukro.cz portal shows that online shopping is not only attractive for the youngest generation of adults, in the running year comparison the number of buyers in the age category over 40 years is growing. While in 2008 online buying was interesting mainly for people over 30 years of age, last year almost seven per cent more people older than 40 years of age overcame their worries according to the study.

People buy online mainly because they can get brand clothes which cannot be found anywhere else in the Czech market. Also the prices are favorable for buyers compared to often exaggerated prices of the goods in the Czech conventional shops. Gemius agency (2009), together with Seznam.cz and Centrum.cz portals, carried out an extensive questionnaire survey focused on online shopping where the main goal was to find out the most frequent motivations for shopping via the Internet. The research results show that the biggest motivation is price $(34 \%)$ and in the second places there are time savings and comfort $(24 \%)$. The third place is taken by product quality with $17 \%$. The motive specified in the next place, pleasant leisure time activity (14\%), implicitly also shopping enjoyment, is opposite to the motives of those who save time here.

\section{SOLVING OF THE PROBLEM}

\subsection{Methods of the research}

The main methods of this article is analysis of current state in the area of online shopping by literature research, methods of interviewing (by questionnaire) in quantitative research, comparison of own results with other research results and methods of statistical induction (Test of Independence, Chi-square test) that verify the formulated hypotheses. 


\subsection{Characterization of the research}

In January and February 2011 the author of the article performed a questionnaire research which was surveying the motives of buyer behavior of selected respondents on the Internet (Svatošová, 2011). The research was carried out in the form of personal and electronic questioning in the district of Pardubice in the Czech Republic. The main aim of the research was to gain data concerning the opinions of buyer behavior of consumers concerning trading through the Internet. As the basic group we chose a group of people from 18 to 74 years of age living in the district of Pardubice (according to Czech Statistical Office, in 2009 127,829 inhabitants 18 to 74 years old lived in the district of Pardubice). The age group 18 - 29 counts $22 \%$ people, $30-39$ is 22,4\%, $40-49$ is $16,8 \%, 50-59$ is $18,4 \%$ and $60-74$ is $20,4 \%$ people. We test the significance level of $\alpha=0.05$.

For the purpose of the survey, we addressed 138 respondents in the form of direct questioning, the total of 122 questionnaires suitable for further processing was returned. In the electronic form we addressed 96 respondents, 84 questionnaires returned. The total of 206 persons took part in the research. The questionnaire contains the total of 17 questions. The first five questions are focused only on the personality of the respondents to be able to sort them according to age, sex, occupation etc. The other questions are already focused on the actual research and they ask about the use of Internet, effects of Internet advertising, online shopping, payment for goods and other opinions. This questionnaire research is made in terms of pre-research that explores environment of e-business therefore it consists of limited number of respondents.

\subsection{Testing of Hypotheses}

Based on analysis of secondary sources, we can be assumed that the main motives of shopping over the Internet are a lower price, convenience of shopping, a wider choice of products and services and their comparison. Therefore questionnaire research verifies that the motives of respondents agree with the generally known results from secondary sources. It can also be assumed (Cetelem.cz, 2011; E15.cz, 2010; Gemius, 2010; ČSÚ, 2011) that the motives of online shopping behavior are changed with age of respondents. For the purposes of this article, the author develops further the earlier questionnaire research where in the form of determined statistic methods, she will confirm or refuse the hypothesis made. For testing of the hypothesis, the test of independence was chosen.

\subsection{Test of Independence}

The following figure 4 shows how many of the respondents addressed buys or has ever bought something via the Internet. The results show that 99 of respondents have ever bought something via the Internet, 55 are thinking of this option. These respondents then answered questions concerning the motives and experience with Internet shopping. These 154 respondents correspond with age distribution of inhabitants in the district of Pardubice, except the age group $60-74$. This value is distorted by reaching respondents on the Internet, because this age group practically does not use this modern medium. 


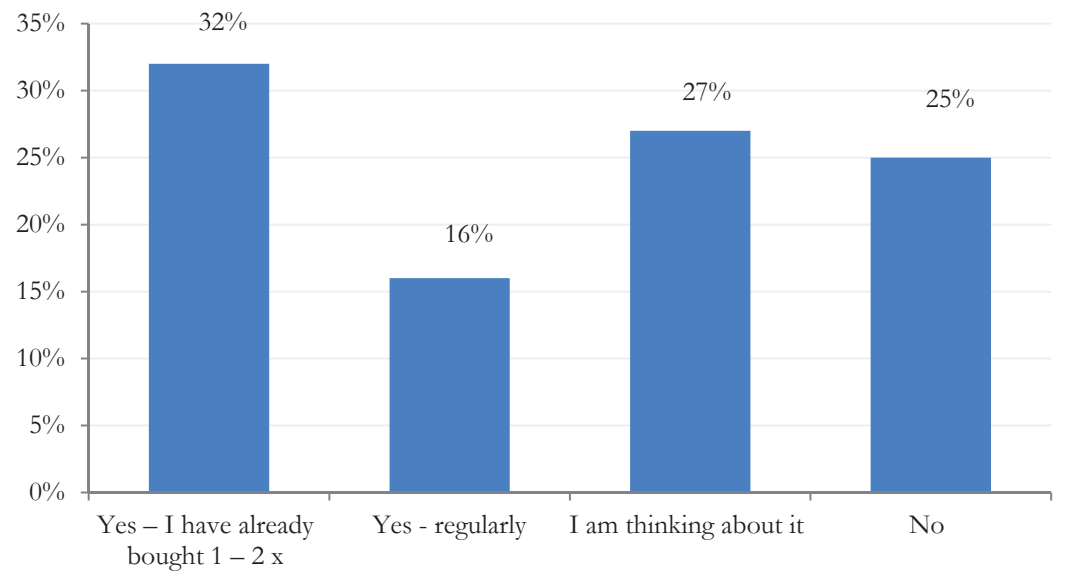

Fig. 4 - Do you buy via the Internet (in \%). Source: own.

Another figure 5 shows a relation between the age of the selected respondents and motivation for the Internet shopping. In the research the respondents were asked what would motivate them to buy online. The selected answer options were prepared on the basis of study of secondary sources performing similar researches in the area of motives of online shopping.

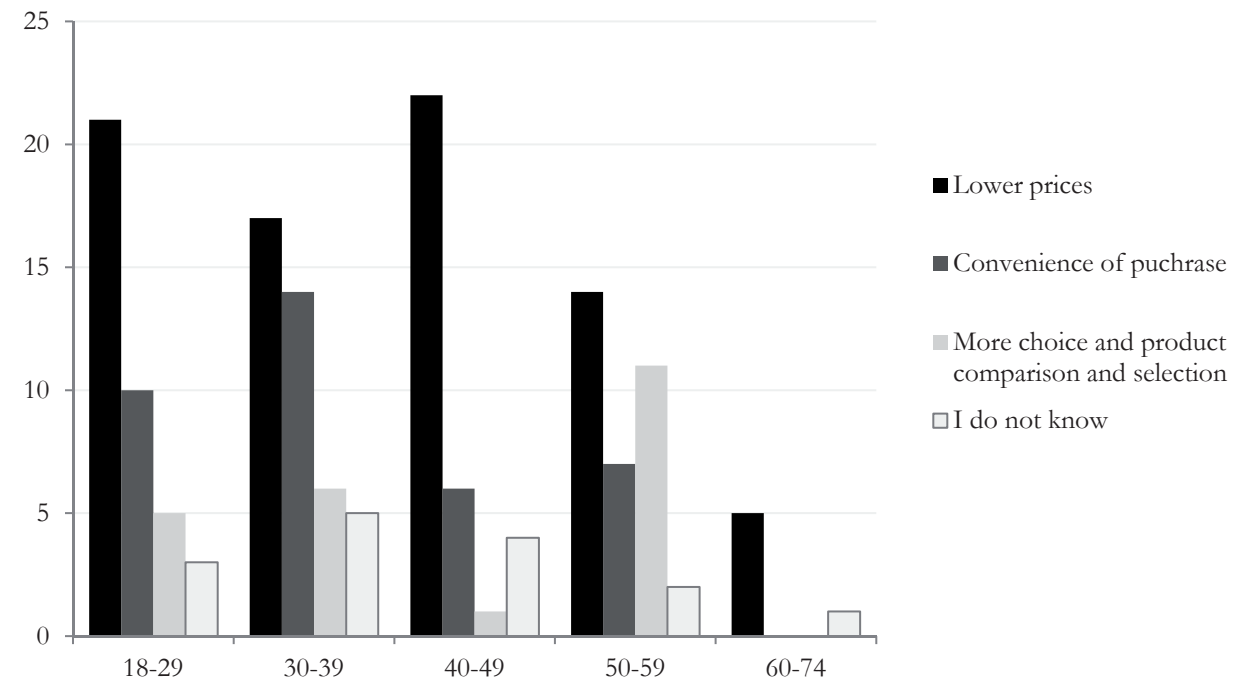

Fig. 5 - Relation between age and motivation to online buying (in \%). Source: own.

By means of the non-parametric test of independence (Kubanová, 2004) we test whether there is a relation between the age of respondents and motivation for the Internet shopping. We test the significance level of $\alpha=0.05$. 
The random quantity $\mathrm{X}$ is age of respondents, the random quantity $\mathrm{Y}$ is motivation for the Internet shopping. We test the zero hypothesis $\mathrm{H} 0$ stating that the random quantities $\mathrm{X}$ and $\mathrm{Y}$ are independent. The alternative hypothesis of H1: $\mathrm{X}$ and $\mathrm{Y}$ are dependent. The testing criterion is as follows (Kubanová, 2004):

$\chi=\sum_{i=1}^{r} \sum_{j=1}^{s} \frac{\left(n_{i j}-\frac{n_{i \bullet} \cdot n_{\bullet j}}{n}\right)^{2}}{\frac{n_{i \bullet} \cdot n_{\bullet j}}{n}}$

The first step is calculation of marginal frequencies for which the following applies:

$n_{i \bullet}=\sum_{j=1}^{s} n_{i j}$ and $n_{\bullet j}=\sum_{i=1}^{r} n_{i j}$

The marginal frequencies and total frequencies are shown in table 2:

Tab. 2 - Marginal and total frequency for calculating the test of independence. Source: own.

\begin{tabular}{|c|c|c|c|c|c|}
\hline & \multicolumn{4}{|c|}{ Motivation to Online Buying } & \multirow{2}{*}{ Sum $n_{i \cdot}$} \\
\cline { 2 - 5 } & & Age of Re- \\
spondents & Lower Prices & $\begin{array}{c}\text { Convenience } \\
\text { of Purchase }\end{array}$ & $\begin{array}{c}\text { More choice } \\
\text { and product } \\
\text { comparison } \\
\text { and selection }\end{array}$ & $\begin{array}{c}\text { I do not } \\
\text { know }\end{array}$ & \\
\hline $18-29$ & 21 & 10 & 5 & 3 & 39 \\
\hline $30-39$ & 17 & 14 & 6 & 5 & 42 \\
\hline $40-49$ & 22 & 6 & 1 & 4 & 33 \\
\hline $50-59$ & 14 & 7 & 11 & 2 & 34 \\
\hline $60-74$ & 5 & 0 & 0 & 1 & 6 \\
\hline Sum $n_{j}$ & 79 & 37 & 23 & 15 & 154 \\
\hline
\end{tabular}

The second task is calculation of the theoretical frequency $\frac{n_{i \bullet} \cdot n_{\bullet j}}{n}$. The third task is calculation of values

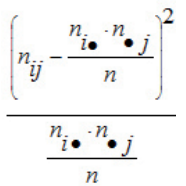

for the individual pairs of indexes, i., j.

We will calculate the value of the testing criterion $\chi$ :

$\chi=\sum_{i=1}^{r} \sum_{j=1}^{s} \frac{\left(n_{i j}-\frac{n_{i \bullet} \cdot n_{\bullet j}}{n}\right)^{2}}{\frac{n_{i \cdot} \cdot n_{\bullet j}}{n}}=20,48137$ 
The critical area is subsequently defined by the relation $\mathrm{W}=\left\{\mathrm{X} ; \mathrm{X}>\mathrm{X}_{\alpha,(\mathrm{r}-1) *(\mathrm{~s}-1)}\right\}$, the critical limit $\mathrm{X}_{\alpha,(\mathrm{r}-1) *(\mathrm{~s}-1)}$ is found in the tables of $\mathrm{X}^{2}$ probability distribution.

The critical limit $\mathrm{X}_{\alpha,(\mathrm{r}-1) *(\mathrm{~s}-1)}=\mathrm{X}_{0,05 ; 12}=21.0261$.

Conclusion: $21.0261>20.48137$. The value of the testing criterion fell into a range of permissible values. We do not refuse $\mathrm{H}_{0}$ hypothesis, random quantities $\mathrm{X}$ and $\mathrm{Y}$ are independent. It means that there is no relation between the age of respondents and motivation for the Internet shopping.

\subsection{Test of coincidence $-\chi^{2}$-test}

Figure 6 generally expresses the experiences of respondents with buying on the Internet. Numeric data serve as a basis for establishing hypotheses (Kubanová, 2004).

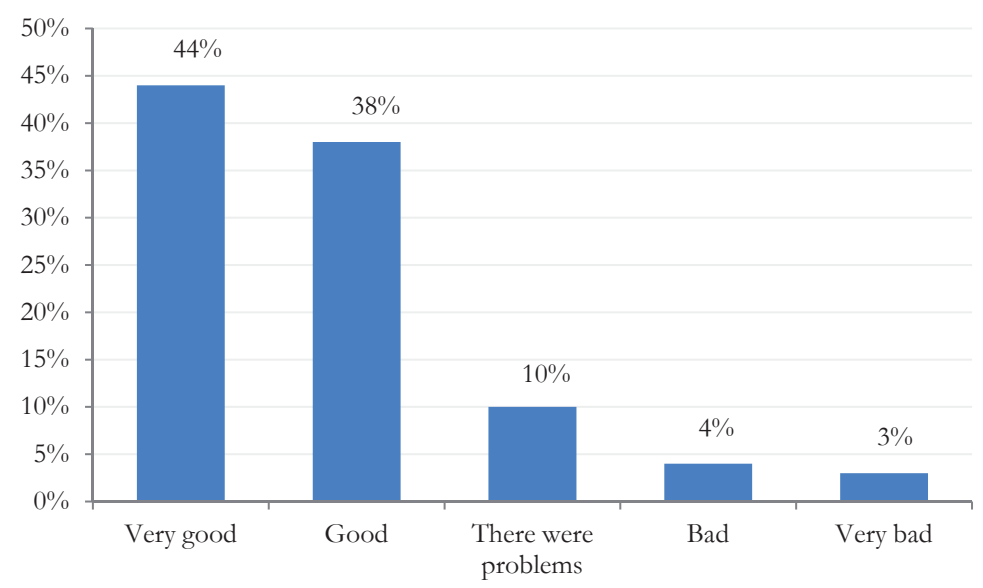

Fig. 6 - Relationship to environment (in \%). Source: own.

Consequently, it is determined by hypothesis using the $\chi^{2}$ - test on a basis of previous graphical results.

$\mathrm{H}_{0}$ : Experiences with buying on the Internet are evenly distributed (there is consensus among respondents who have very good, good, problematic, bad and very bad experiences with buying on the Internet).

$\mathrm{H}_{1}$ : Experiences with buying on the Internet are not evenly distributed (there is no consensus among respondents who have very good, good, problematic, bad and very bad experiences with buying on the Internet).

The value of the $\chi^{2}$ - test is:

$$
\chi^{2}=\sum_{i=1}^{n}=\frac{\left(O_{i}-E_{i}\right)^{2}}{E_{i}}
$$


Legend:

$O_{i}=$ an observed frequency;

$E_{i}=$ an expected (theoretical) frequency, asserted by the null hypothesis;

$E_{i}=n p_{i}, n=$ the number of cells in the table, $\mathrm{pi}=$ probability of the $\mathrm{i}^{\text {th }}$ class in the expected probability distribution.

Substituting in the formula:

$\mathrm{n}=99$

$\mathrm{E}_{1}=19,8, \mathrm{E}_{2}=19,8, \mathrm{E}_{3}=19,8, \mathrm{E}_{4}=19,8, \mathrm{E}_{5}=19,8$

$\mathrm{O}_{1}=44, \mathrm{O}_{2}=38, \mathrm{O}_{3}=10, \mathrm{O}_{4}=4, \mathrm{O}_{5}=3$

$$
\chi^{2}=\frac{(44-19,8)^{2}}{19,8}+\frac{(38-19,8)^{2}}{19,8}+\frac{(10-19,8)^{2}}{19,8}+\frac{(4-19,8)^{2}}{19,8}+\frac{(3-19,8)^{2}}{19,8}=78,0202
$$

It is tested at a level of significance $\alpha=0.05$. The critical area is then defined by the relation $\mathrm{W}=$ $\left\{X ; X>X_{a, n-1}^{2}\right\}$, critical limit $X_{a, n-1}^{2}$ is looked up in tables $X^{2}$ probability distribution.

Critical limit is $X_{0,05,5-1}^{2}=X_{0,05,4}^{2}=9,48773$

Conclusion: 78,0202 >9,48773. The value of the test-statistic fell into a region of rejection. Differences between actual and expected distribution of probabilities are high, therefore there is disagreement and $\mathrm{H}_{0}$ is clearly rejected. The result shows that the experiences with buying on the Internet are not evenly distributed.

\section{RESULTS AND DISCUSSION}

The Maslow's hierarchy of needs still shows its topicality as regards the current possibilities of a business and marketing conception. However, we can see that motives cannot be deduced easily from the consumer's behavior as motivation is a highly dynamic process which changes constantly in reaction to the life experience. Success of a company is connected mainly with satisfaction of the consumer's needs which were categorized by Maslow in five independent grades. Acceptance of this theory will make understanding of the main motives of consumers easier to understand and buyer behavior will subsequently be influenced by the seller or manufacturer.

By means of the independence test it was examined whether there is a relation between the age of respondents and motivation for online shopping. In this respect, the hypothesis was not rejected - there is no relation between age of respondents and motives to online shopping. This means that respondents in various age groups have different motives to the buying on the Internet. This conclusion shows that the target group is potential customers in the age 18 - 35 years old (according to statistical data CSO, 2012). This target group is mostly focused on buying of goods that is exclusive, special goods or cost-effective. The other age groups (under 18, over 35) are in motives different - convenience of online buying or curiosity. Especially marketers should take this fact into account.

The other test of coincidence ( $X^{2}$-test) has rejected the hypothesis that experiences with buying on the Internet are not evenly distributed. This means that respondents have more positive experiences with buying on the Internet than negative. This conclusion shows that safety and con- 
fidence in online buying is increasing but there are still speculations to dishonest online sellers. From the research of bibliography and other sources it is clear that besides known factors influencing online buyer behavior there is also other influence, such as social media in the form of social networks, blogs and other instruments. Discussion forums, sharing of opinions and experience on social medias influences significantly the final decisions of users for online shopping. Therefore it is important for online traders to include this marketing tool of their online business activities in the strategy of the company.

The questionnaire survey carried out in person showed that $48 \%$ of respondents have already bought something on the Internet, $16 \%$ of which buys regularly which is a result below average compared to the results from other relevant surveys. The survey also showed that the biggest motivation for purchase on the Internet is lower prices, also convenient shopping and a wider range of goods and finally also a possibility of a bigger choice, which corresponds to the other researches carried out in this subject. $65 \%$ of respondents are planning further purchases on the Internet for future. Most often the respondents buy books, music, software, electrical appliances and tickets to various events and this result again corresponds to other researches. (Svatošová, 2011)

It is sure that traditional marketing and Internet marketing include other features by means of which it is possible to influence shopping behavior. With regard to the fact that today's consumers are more and more resistant to these stimuli, social media may represent the main direction in which it is possible to go in the area of online buyer behavior. For example the social network Facebook (Facebook, 2011). came with quite an untraditional solution when besides the existing website by means of which it is possible to promote a certain product or brand in a targeted way in these networks, as a new feature it is possible to establish an e-shop directly on Facebook and mediate thus a closer contact with your potential customers.

\section{CONCLUSION}

The aim of the article was to analyze behavior of consumers when shopping on the Internet and their motives. The resulting data show that awareness of the Internet and its use in everyday life is constantly increasing, which means that goals of this article have been fulfilled. Naturally, some stimuli are identical with the generally known customer behavior during purchase. Despite that we can say that electronic trading has its special features and differences. Everybody who wants to enter the network world in order to offer their products and services there must be aware of the distinctive approach, count on it and adapt to it. The results show that motives of online shopping behavior are independent on age of respondents. Motives in each age group are the same and marketers do not have to select motives of online shopping according to age of respondents.

\section{Acknowledgement}

This contribution was supported by the research project SGFES03 "Scientific Research in Economics and Management". 


\section{References}

1. APEC: Association for electronic commerce. (2012). O asociaci: Trh elektronickébo obchodu v Ceské republice. Retrieved May 18, 2012, from: http://www.apek.cz/

2. Bělohlávek et al. (2001). Management. Olomouc: Rubico.

3. Bhatnagar, A., Misra, S., \& Rao, H. R. (2000). On risk, convenience, and Internet shopping behavior. Communications of the ACM, 43(11), 98-105. http://dx.doi.org/10.1145/353360.3533 71

4. Blažek, L. (2011). Management: organizováni, roz̧odování, ovlivňování. Prague: Grada Publishing.

5. Castaneda, J. A. et al. (2009). Attitude's hierarchy of effects in online user behavior. Online Information Review, 33(11), 7-21. http://dx.doi.org/10.1108/14684520910944364

6. Cetelem.cz (2011). Barometr Cetelem. Retrieved July 13, 2012, from: http://www.cetelem. cz/o-nas/informace-pro-media/barometr-cetelem.html

7. Chaffer, D. et al. (2006). Internet Marketing Strategy, Implementation and Practice. New York: Pearson Education.

8. Chuang, C. C., Hu F. (2012). An empirical analysis of the relationship between website characteristics and consumer online buying behavior. Interdisciplinary Journal of Contemporary Research in Business, 4(7), 286-294.

9. Cimpler, P. (2005). Územní analýza nákupního chování. E+M: Ekonomie a management, 4, $114-118$.

10. CSO: Czech Statistical Office. (2012). [quot. 2012-06-14]. Informační společnost v čislech 2012. Retriewed June 14, 2012, from: http://www.czso.cz/csu/2012edicniplan.nsf/p/9705-12

11. CSO: Czech Statistical Office. (2013). 21. 1. 2013 [quot. 2013-03-14]. Využití internetuv maloobchodě. Retrieved March 14, 2013, from: https://www.czso.cz/csu/csu.nsf/informace/ c012113analyza13.doc

12. E15.cz. (2010, April 28). Zájem o nakupování na Internetu nadále roste. E15.cæ. Retrieved July 13, 2012, from: http://zpravy.e15.cz/byznys/obchod-a-sluzby/zajem-o-nakupovani-nainternetu-stale-roste

13. Facebook. (2011). Internetový obchod na Facebooku. Retrieved July 13, 2012, from: http://www. facebook-obchod.cz/

14. Gemius. (2010). Marketing Research. [online]. Retrieved July 13, 2012, from: http://cz.gemius. $\mathrm{com} / \mathrm{cz} /$

15. Grewal, D., Iyer, G. R., \& Levy, M. (2004). Internet retailing: enablers, limiters and market consequences. Journal of Business Research, 57(7), 703-713.

16. Gurvinder S. S., \& Zhaobin C. (2005). Web-based shopping: consumers' attitudes towards online shopping in New Zealand. Journal of Electronic Commerce Research, 2(6), 79-94.

17. Kneschke, J. (2006, April 18). Lidé nákup zdůvodňují fakty, ale rozhodují se na základě pocitů. Marketingové noviny. Retrieved July 13, 2012, from: http://www.marketingovenoviny. $\mathrm{cz} /$ index.php3?Action=View\&ARTICLE_ID $=4129$

18. Koufaris, M. (2002). Applying the Technology Acceptance Model and Flow Theory to Online Consumer Behavior. Information Systems Research, 13(2), 205-223. http://dx.doi. org/10.1287/isre.13.2.205.83

19. Kubanová, J. (2004). Statistické metody pro ekonomickou a tecbnickou praxi. Bratislava: Statis. 
20. Lee, M. K. O., \& Turban, E. (2001). A trust model for consumer internet shopping. International Journal of Electronic Commerce, 6(1), 75-91.

21. Lösch, A., \& Lambert J. S. (2007). E-Reverse Auctions Revisited: An Analysis of Context, Buye-Supplier Relations and Information Behavior. The Journal of Supply Chain Management, 43(4), 47-63. http://dx.doi.org/10.1111/j.1745-493X.2007.00040.x

22. Měšec.cz. (2010, November 4). 9 z 10 Čechů nakupuje na internetu - Kreditní kartou na internetu platí zatím jen $6 \%$ nakupujících. Měsec.c\%. Retrieved July 13, 2012, from: http:// www.mesec.cz/tiskove-zpravy/9-z-10-cechu-nakupuje-na-internetu-kreditni-kartou-nainternetu-plati-zatim-jen-6-nakupujicich/

23. Petrtyl, J. (2012). Security and Trustworthiness as Drivers of E-shop Competitiveness (Opinions of Young Customers). Journal of Competitiveness, 4(1), 83-97. http://dx.doi. org/10.7441/joc.2012.01.07

24. Pilík, M. (2012). Online Shopping on B2C Markets in the Czech Republic. Journal of Competitiveness, 4(4), 37-49. http://dx.doi.org/10.7441/joc.2012.04.03

25. Röszlerová, A. (2010, April 26). Češi i Evropané výrazně mění nákupní chování. Retailinfo Plus. Retrieved July 13, 2012, from http://www.retailinfo.cz/magazin/clanky/cesi-ievropane-vyrazne-meni-nakupni-chovani

26. Schiffman, L. G., \& Kanuk, L. L. (2004). Nákupní chování. Brno: Computer Press.

27. Singh, S. N., \& Dalal, N. P. (1999). Web home pages as advertisements. Communications of the ACM, 42(8), 91-98. http://dx.doi.org/10.1145/310930.310978

28. Smith, A. D., \& Rupp, W. T. (1997). Strategic online customer decision making: leveraging the transformational power of the Internet. Online Information Review, 27(6), 418-432. http:// dx.doi.org/10.1108/14684520310510055

29. Solomon, M. R., Marshal, G. W., \& Stuart, E. W. (2006). Marketing očma svétových marketing manažeru. Brno: Computer Press.

30. Svatošová, V. (2011). Marketing Research - Purchasing Behaviour on the Internet. In Mezinárodni Batova konference. Zlín: Tomas Bat’a University in Zlín.

31. Vellido, A., Lisboa, P. J. G., \& Meehan, K. (2000). Quantitative characterization and prediction of on-line purchasing behavior: A latent variable approach. International Journal of Electronic commerce, 4(4), 83-104.

32. Vijayasarathy, L. R. (2002). Internet taxation, privacy and security: Opinions of the taxis and legislated. Quarterly Journal of Electronic Commerce, 3(1), 53-71.

33. Wolfinbarger, M., \& Gilly, M. C. (2003). EtailQ: dimensionalizing, measuring and predicting etail quality. Journal of Retailing, 79(3), 183-198. http://dx.doi.org/10.1016/S00224359(03)00034-4

\section{Contact information}

Ing. Veronika Svatošová

University of Pardubice, Faculty of Economics and Administration

Studentská 95, 53210 Pardubice, Czech Republic

E-mail:veronika.svatosova@student.upce.cr. 